\title{
空中浮遊菌測定器の生物粒子捕集性能
}

\author{
山㠃省二 \\ 国立保健医療科学院 客員研究員 \\ テ351-0197 埼玉県和光市南2-3-6

\section{Collection efficiency of biological particles on airborne bacteria samplers}

\author{
Shoji YAMAZAKI, A guest researcer \\ National Institute of Public Health. \\ 2-3-6 Minami, Wako-shi, Saitama 351-0197, Japan
}

\section{要 旨}

生物粒子を用いて空中浮遊菌測定器の捕集性能を調べた報告は少ない。

著者らは1970年代に購入可能であった空中浮遊菌測定器 5 種の生物粒子捕集性能を菌噴霧実験チャンバー を用いて調べ，衝突型のスリットサンプラー(Casella)が優れた捕集性能を持つことを知った。しかしこの 成績は定性的であった。定量的な成績を得るため, 空中浮遊菌測定器の生物粒子捕集性能試験方法を開発し た。この捕集性能試験方法を用いて衝突型空中浮遊菌測定器6種類の生物粒子捕集性能を調べた結果, 器種 により捕集性能に差が認められた。また，携帯型は定置型測定器に比較し明らかに捕集性能が低かった。

その後, 仲田らは生物粒子の捕集性能を重視した携帯型測定器を開発し(1999年), その生物粒子捕集性能 を前述の試験方法を用いて定量的に調へ，携帯型においても定置型同様の高い生物粒子捕集性能を有するこ とを報告した。ここではこれらの成績を紹介する。

\begin{abstract}
There were few reports on the collection efficiency of the airborne bacteria sampler using biological particles in a laboratory.

We studied collection efficiency on the 5 kinds of samplers for biological particles using the test chamber atomized microorganisms and proved the slit sampler (casella) of the impaction type show surpassing collection efficiency in 1970. However, as the study was qualitative, we have developed the skillful method and designed the test equipment for collection efficiency using biological particles of the samplers and performed a quantitative experiment. (1993) As the results of these experiments, the collection efficiency of samplers indicates the significant difference and the collection efficiency of the portable type samplers indicates lower than that of the fixed type samplers.

Nakata et al. developed the portable sampler which has as high collection performance as fixed type samplers examined by the above quantitative method. (1999)

Here, we introduce these results.
\end{abstract}

Key words: 空中浮遊菌 (Airborne bacteria), 空中浮遊菌測定器 (Airborne bacteria samplers), 捕集性能 (Collection efficiency), 生物粒子 (Biological particles), 枯草菌芽胞 (Spore of Bacillus subtilis)

\section{1。はじめに}

パスッールは1860年に室内の空気中に微生物が存 在することを肉汁ブイヨンを用いて初めて証明し， コッホは1881年にジャガイモを主成分とする固形培 地を用い，空気から微生物を回収した。その後，多 くの人々が空中浮遊菌測定器を開発しだが生物粒 子を用いて捕集性能を示したものは少ない。
1959年に米国のPublic Health Monograph ${ }^{2)}$ で空中 浮遊菌測定器に関する詳細な報告がなされ，1963年 にカリフォルニア大学バークレイ校で空中浮遊菌測 定器に関する国際会議が開かれ, 空中浮遊菌測定器 は現在(1963年)のところArtであるとしだ)。1967年 には宇宙開発に伴う問題として，宇宙に微生物を持 ち込まない，宇宙から微生物を地球に持ち込まない ことを目的に空中微生物の捕集・分離などが検討さ れた ${ }^{4,5)}$ 。同年英国のインペリアルカレッジで空中微 
生物に関するシンポジュームが開かれ, 検討内容が 著書(6)に記された。また，1969年に空中微生物の一 般性状に加え，空中微生物の捕集・分離などに関す る詳細な内容の著書がディミイックフらにより出さ れた。

国際的には世界標準機構(ISO)でバイオコンタミ ネーションの国際規格化が1994年から討議され，こ の中で空中浮遊菌測定器の生物粒子捕集性能の検定 も検討されており，現在JIS化が検討されている。

日本では生物粒子を用いて各種空中浮遊菌測定器 の捕集性能比較が1980年に報告された ${ }^{8}$ 。また，工 業技術院委託調査研究で空中浮遊菌測定器の生物粒 子捕集性能試験方法を検討し，1991，1993年に報告

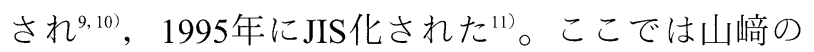
1980年の報告 ${ }^{8)}$ とJIS化された捕集性能試験方法を用 いて行った各種空中浮遊菌測定器の生物粒子捕集性 能結果 ${ }^{9}{ }^{10)}$ について述べる。

\section{2. 空中浮遊菌測定器の生物粒子捕集性能}

\section{1 菌噴霧実験チャンバーを用いた空中浮遊菌測 定器の生物粒子捕集性能比較}

山㟝”らは1970年代当時, 購入可能であった空中 浮遊菌測定器のうち, 落下法 $(9 \mathrm{~cm} \phi$ シャーレ), ス リットサンプラー(Casella), ガラスインピンジャー (AGIミリポア), サーマルプレシピィティ夕(水冷 式, Am. In. Co.) の生物粒子捕集性能を菌噴霧実験 用チャンバーを用いて比較した。結果を表1に示す。 乳児由来の非病原性大腸菌 (Escherichia coli)をアト マイザ(ネブライザ)でチャンバー内に吹き込み, 空
気1ににつき270個(計算值)を浮遊させると, 落下法 では5分間の暴露で1個のコロニーが $\left(37^{\circ} \mathrm{C} 24\right.$ 時間培 養), スリットサンプラーは2分間 $62 \ell$ サンプリン グで809個，ガラスインピンジャーでは5分間71lの サンプリングで119個が認められ，サーマルプレシ ピィティタでは大腸菌のコロニーが認められなく, スリットサンプラーの捕集性能が優れていた。

スリットサンプラー(Casella), ガラスインピンジャー (AGIミリポア), メンブレンフィルタ標準法(ミリ ポア）の生物粒子捕集性能を比較した結果を表2に示 す。非病原性大腸菌を空気 $1 \ell に つ き 240$ 個(計算值) 浮遊させるとスリットサンプラーは2分間62lのサン プリングで725個のコロニーが, 全グラスインピン ジャーでは5分間で62.5eのサンプリングで97個，メ ンブレンフィルタ標準法では5分間62.5lのサンプリ ングで39個が認められ，スリットサンプラーでの捕 集効率が高かった。

これらの結果から衝突型空中浮遊菌測定器スリッ トサンプラー (Casella)は優れた生物粒子捕集性能を あつ測定器であることが知られた。しかしこのスリッ トサンプラーは高価であり，大きく重く，移動が困 難である，音が大きい，などの欠点があり実用的で ないため，著者らはスリットサンプラーの理論をも とに欠点を改良した空中浮遊菌測定器を開発(ピン ホールサンプラ)した。その生物粒子捕集性能を菌 噴霧実験チャンバーに霊菌 (Serratia marcescens) を アトマイザで噴霧し，スリットサンプラーと比較検 討した結果を表3に示す。環境由来の霊菌を空気1 $\ell$ につき78個(計算值)を浮遊させるとピンホールサン

\section{表1 空中浮遊菌測定器の生物粒子捕集性能 - 1}

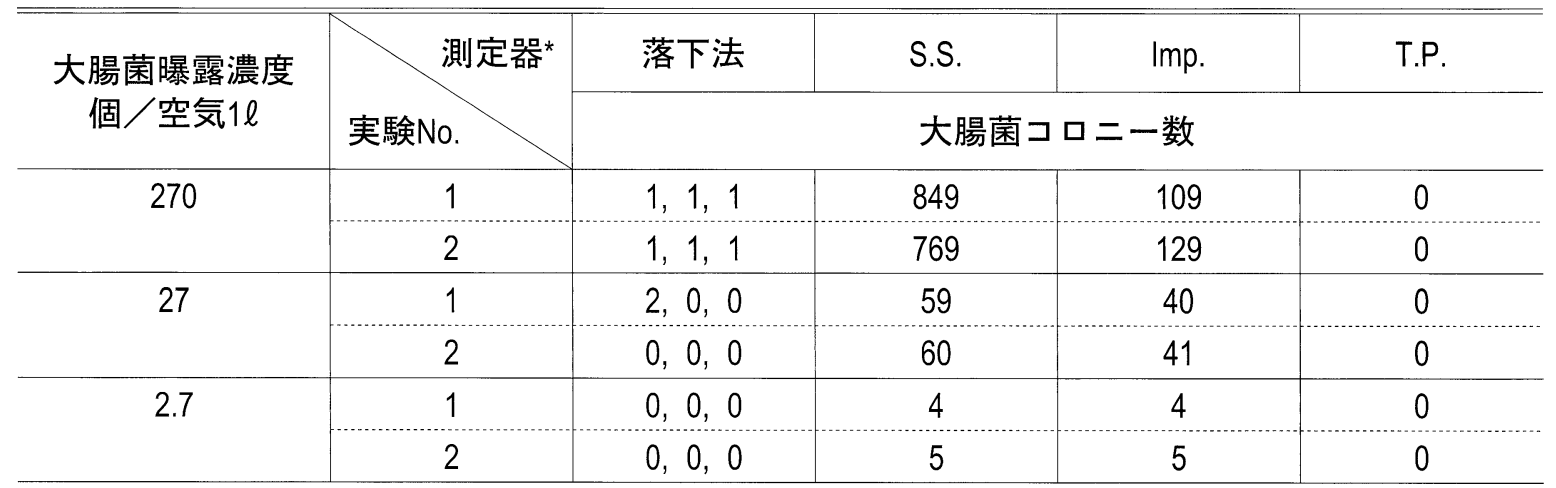

* 測定器

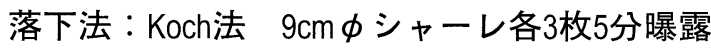

S.S. : Slit Sampler (Casella)吸気量31/lmin，2分

Imp. : Glass Impinger(ミリポア)吸気量12.5l/min, 5分

T.P. : Thermopositor (Am. In. Co.) 吸気量 $6 / / m i n, 10$ 分 
表2 空中浮遊菌測定器の生物粒子捕集性能 -2

\begin{tabular}{c|c|c|c|c}
\hline \multirow{2}{*}{$\begin{array}{c}\text { 大腸菌曝露濃度 } \\
\text { 個 } / \text { 空気1l }\end{array}$} & 測定器* & S.S. & Imp. & M.F. \\
\cline { 2 - 5 } & 実験No. & \multicolumn{3}{|c|}{ 大腸菌コロニー数 } \\
\hline 240 & 1 & 743 & 93 & 41 \\
\hline 24 & 2 & 706 & 106 & 37 \\
\hline & 1 & 72 & 28 & 10 \\
\hline & 2 & 68 & 36 & 14 \\
\hline
\end{tabular}

$*$ 測定器

S.S. : Slit Sampler (Casella) 吸気量31 l/min, 2分

Imp. : Glass Impinger(ミリポア)吸気量 $12.5 / / \mathrm{min}, 5$ 分

M.F. : Membrain Filter(ミリポア)吸気量12.5//min，5分

表3 空中浮遊菌測定器の生物粒子捕集性能 -3

\begin{tabular}{c|c|c}
\hline \hline \multirow{2}{*}{$\begin{array}{c}\text { 霊菌曝露濃度 } \\
\text { 個 } / \text { 空気1l }\end{array}$} & P.S. & S.S. \\
\cline { 2 - 3 } & \multicolumn{2}{|c}{ 霊菌コロニー数定器* } \\
\hline 78 & $504.5 \pm 47.8$ & $540.0 \pm 48.0$ \\
\hline 空気1l当りの捕集菌数 & 9.52 & 8.71 \\
\hline 7.4 & $20.0 \pm 2.7$ & $17.2 \pm 2.3$ \\
\hline 空気1l当りの捕集菌数 & 0.38 & 0.28 \\
\hline
\end{tabular}

$*$ 測定器

P.S. : ピンホールサンプラ (三基)吸気量 $26.5 \ell / \mathrm{min}, 2$ 分

S.S. : スリットサンプラ (Casella) 吸気量31 l/min, 2分

プラは2分間53lのサンプリングで505個のコロニー が，スリットサンプラーでは2分間64lのサンプリン グで540個が認められ，捕集空気 $1 \ell$ 当たりの捕集菌 数はピンホールサンプラ9.5個, スリットサンプラー 8.7個であり，両者の捕集性能は同程度であった。

しかし，これらの成績は大腸菌や霊菌の菌噴霧実 験用チャンバー内での消長が不明であるため, 定量 的ではなく，定性的である。

\subsection{JISの生物粒子捕集性能試験方法による空中 浮遊菌測定器の生物粒子捕集性能比較}

\section{2.1 衝突型空中浮遊菌測定器の生物粒子捕集性能 比較}

1995年にJIS化 ${ }^{11)}$ れた捕集性能試験方法を用い て, 山㟝ら ${ }^{10)}$ は現在広く利用されている衝突型空中 浮遊菌測定器の菌捕集性能試験を行なった。測定器 は入手が容易で，比較的広く利用されている6種類 を選び，捕集性能を調べるための生物粒子(菌)は, 乾燥などの物理的条件に強く, アトマイザ(ネブラ
イザ)などの発生器を用いても死滅せず安定で, 単 体で発生できる，ヒトに危険がない，污染菌と区別 が容易にできるなどの理由から, 枯草菌芽胞 (Bacillus subtilis globigii ATCC9372, 中心粒子径 $0.7 \mu \mathrm{m}$ )を 用いた。試験装置を図1に示す。

測定した衝突型空中浮遊菌測定器の仕様と測定結 果を表4, 表5に示す。衝突型空中浮遊菌測定器 $\mathrm{A}, \mathrm{B}$, Cはほぼ100\%の捕集性能を示し，Dの捕集性能は約

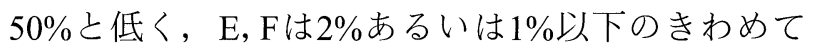
低い捕集性能を示した。この成績は非生物粒子の DOPエアロゾルを用いた実験成績とよく一致した。 (図2,3)

この成績から衝突型空中浮遊菌測定器の捕集性能 は器種によりばらつきがあることがわかった。また， 試験に用いた衝突型空中浮遊菌測定器A, B, C, Dは, 動力源に $100 \mathrm{~V} の \mathrm{AC}$ 電源を用いた定置型でE, Fはバッ テリーを用いたDC電源の携帯型であったが，携帯 型の捕集性能は明らかに低かった。

これら電池使用の携帯型測定器E, Fが示した極め 


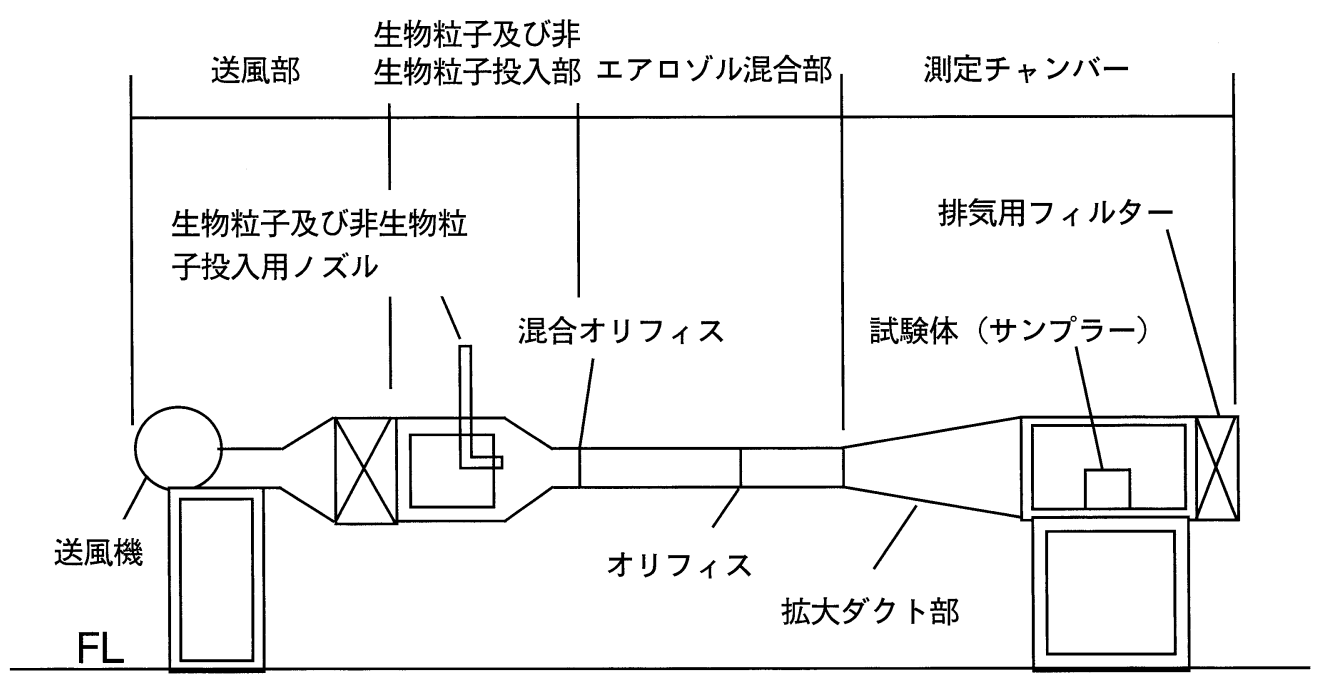

図1 空中浮遊菌測定器の捕集性能試験装置

表4 衝突型空中浮遊細菌測定器の仕様と細菌 (枯草菌茅胞) 捕集性能

\begin{tabular}{c|c|c|c|c|c|c}
\hline \hline 測定機種 & ポンプ & $\begin{array}{c}\text { 吸引流量 } \\
(\mathrm{L} / \text { 分 })\end{array}$ & $\begin{array}{c}\text { シャーレ径 } \\
(\mathrm{cm})\end{array}$ & $\begin{array}{c}\text { 本体サイズ } \\
(\mathrm{mm})\end{array}$ & $\begin{array}{c}\text { 質量 } \\
(\mathrm{kg})\end{array}$ & $\begin{array}{c}\text { 細菌捕集性能 } \\
(\%)\end{array}$ \\
\hline A & 外付 & 28.3 & 9 & $108 \times 203$ & 2.5 & 約100 \\
B & 外付 & $27 \sim 30$ & 9 & $150 \times 150 \times 185$ & 3.0 & 約100 \\
C & 内臓 & 28.3 & 15 & $254 \times 305 \times 305$ & 7.4 & 約100 \\
D & 外付 & 30 & 9 & $250 \times 250 \times 305$ & 7.5 & 約 50 \\
E & 内臓 & 90 & 5.5 & $105 \times 335$ & 2.1 & 2 以下 \\
F & 内臓 & 40 & $2 \times 18.5$ & $70 \times 335$ & 1.1 & 1以下 \\
\hline
\end{tabular}

表5＼cjkstart衝突型空中浮遊菌測定器の細菌捕集性能

\begin{tabular}{|c|c|c|c|c|c|c|c|c|c|}
\hline & \multicolumn{9}{|c|}{ 1 $\mathrm{ft}^{3}$ あたりの捕集細菌コロニー数と95\%信頼区間 } \\
\hline \multirow{6}{*}{ 測定器種 } & A & 1.66 & $1.08-2.58$ & 29.9 & $25.8-33.9$ & 100 & $93-106$ & - & - \\
\hline & B & 1.92 & $1.52-2.43$ & 28.1 & 25.4-30.9 & 85.2 & $80.7-89.7$ & 235 & $218-252$ \\
\hline & C & 1.75 & $1.15-2.68$ & 22.2 & $19.7-24.7$ & 88.8 & 82.6-94.9 & - & - \\
\hline & D & 0.55 & $0.275-1.13$ & 12.0 & $9.76-14.7$ & 50.3 & $45.2-55.4$ & - & - \\
\hline & $E$ & 0 & $0.02-3.69$ & - & - & 0.27 & $0.13-0.59$ & 0.14 & $0.075-0.27$ \\
\hline & $\mathrm{F}$ & - & - & - & - & 0 & $0.02-3.69$ & 0.28 & $0.15-0.56$ \\
\hline \multicolumn{2}{|c|}{$\begin{array}{c}\text { 噴霧菌液濃度 } \\
\text { (CFU/ml) }\end{array}$} & \multicolumn{2}{|r|}{$3 \times 10^{4}$} & \multicolumn{2}{|c|}{$5 \times 10^{5}$} & \multicolumn{2}{|c|}{$1.5 \times 10^{6}$} & \multicolumn{2}{|r|}{$1 \times 10^{7}$} \\
\hline \multicolumn{2}{|c|}{$\begin{array}{c}\text { 浮遊粒子数 (細菌) } \\
\text { 濃度 }\left(\text { 個/ } / \mathrm{ft}^{3}\right)^{*}\end{array}$} & \multicolumn{2}{|r|}{1.75} & \multicolumn{2}{|r|}{24.4} & \multicolumn{2}{|r|}{86.1} & \multicolumn{2}{|r|}{-} \\
\hline
\end{tabular}

*パーティクルカゥンターで計測した粒子数 


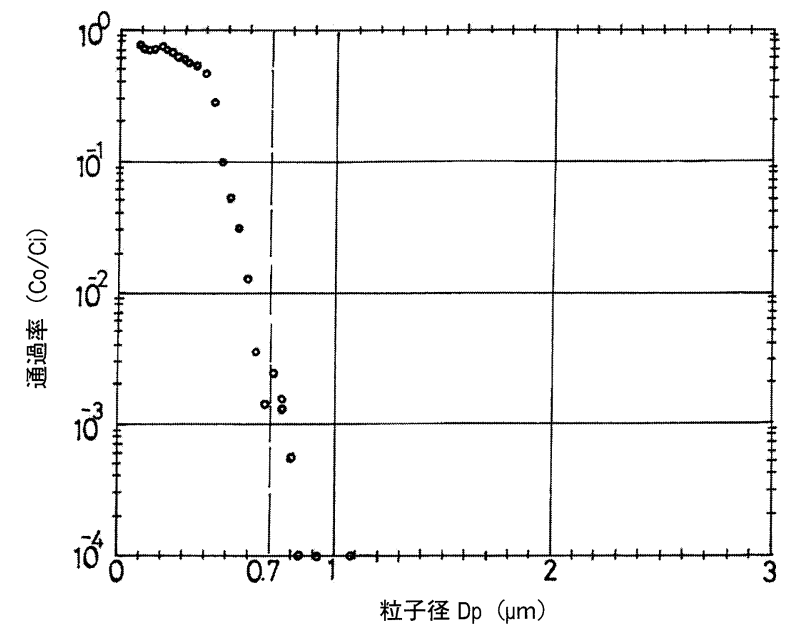

図2 非生物粒子を用いたB測定器の捕集性能

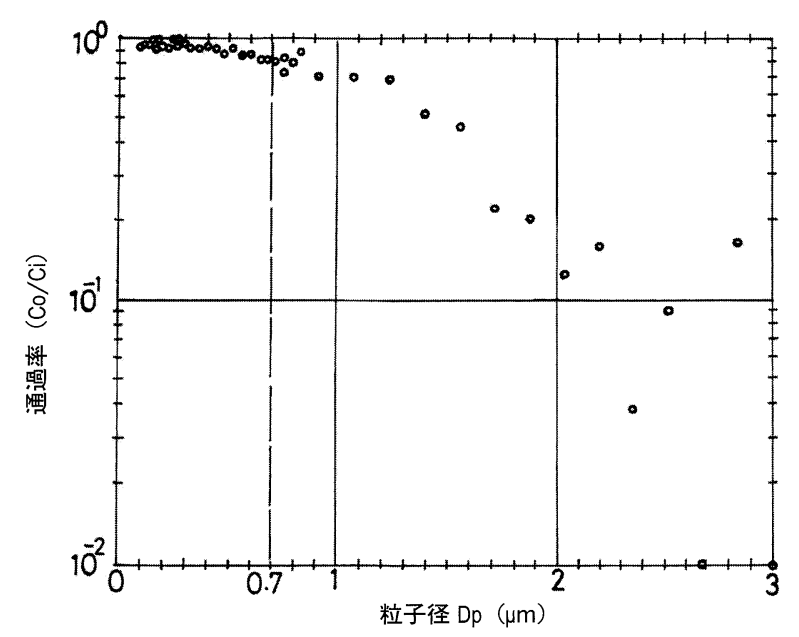

図3非生物粒子を用いたE測定器の捕集性能

て低い捕集性能は, 生物粒子の安定性などの問題か ら比較的小さな粒子径 $(0.7 \mu \mathrm{m}$ 中心径) をあつ枯草 菌芽胞を生物粒子として用いた影響む考えられた。 しかし， AC電源の定置型測定器A，B，Cはほぼ100\% の捕集性能を示しておう, 生物粒子の捕集性能を重
視した携帯型測定器の開発が待たれた。

\section{2.2 携帯型空中浮遊菌測定器の生物粒子捕集性能}

実際に市場で普及し, 多く使用されている空中浮 遊菌測定器は携帯型であり, 定置型は持ち運びに不 便さがあり，また，測定場所によってはAC電源の とれない場合ああり, 捕集性能が高いとはいえ定置 型の使いにくい点は否めない。仲田ら ${ }^{22}$ は, 携帯型 で高い捕集性能を有する空中浮遊菌測定器の開発に 取り組み, 開発した測定器の生物粒子捕集性能を調 べ報告している。JISの菌捕集性能試験方法を用い, 生物粒子として枯草菌芽胞と, $0.8 \mu \mathrm{m}$ の中心径を屯 つルテウス球菌 (Micrococcus luteus) を用い, 定置型 空中浮遊菌測定器のピンホールサンプラと捕集性能 を比較している。新しく開発された多孔板法による 携帯型測定器Aのほか，1997年にドイッで開発され

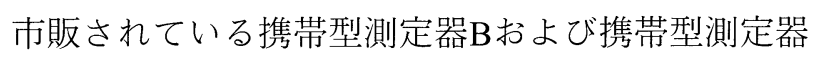
$\mathrm{C}, \mathrm{D}$ (前述の $\mathrm{E}, \mathrm{F}$ ) も併せて調べている。

生物粒子に枯草菌芽胞を用いると, 市販の携帯型 测定器 $\mathrm{B}, \mathrm{C}, \mathrm{D}$ はいずれもきわめて低い捕集性能を 示したが, 新たに開発された携帯型測定器Aは定置 型測定器ピンホールサンプラと同一の高い捕集性能 を示した。(表6)

生物粒子を枯草菌芽胞よりやや大きい粒子径をむ つルテウス菌にすると, 測定器C, Dの低い捕集性 能は变らなかったが, 測定器Bでは捕集性能が5\%か

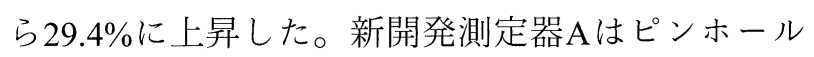
サンプラと同一( $99 \%$ 以上)の高い捕集性能を示した。 (表7)

バッテリーを動力源とする携帯型測定器において あ，改良を加えれば100Vの $\mathrm{AC}$ 電源を動力とする定 置型と同様の $100 \%$ 近い生物粒子捕集性能を有する ことが報告された。

表6 新開発および市販の携帯型空中浮遊菌測定器の枯草菌芽胞捕集性能

\begin{tabular}{|c|c|c|c|c|c|c|c|c|}
\hline \multirow{3}{*}{$\begin{array}{c}\text { 枯草菌芽胞 } \\
\text { 菌液濃度 } \\
\left(6.5 \times 10^{6} \mathrm{CFU} / \mathrm{mL}\right)\end{array}$} & \multirow{2}{*}{\multicolumn{2}{|c|}{$\begin{array}{c}\text { 新開発測定器 } \\
\text { 測定器A }\end{array}$}} & \multicolumn{6}{|c|}{ 市販測定器 } \\
\hline & & & \multicolumn{2}{|c|}{ 測定器B } & \multicolumn{2}{|c|}{ 測定器C } & \multicolumn{2}{|c|}{ 測定器D } \\
\hline & 基準器* & $A$ & 基準器* & B & 基準器* & C & 基準器* & D \\
\hline $\begin{array}{c}\text { 平均コロニー数 } \\
(\mathrm{CFU} / 28.3 \mathrm{~L})\end{array}$ & 88.0 & 89.6 & 113.2 & 5.8 & 66.2 & 4.3 & 86 & 4.1 \\
\hline 95\%信頼区間 & $\begin{array}{r}80.9 \sim \\
95.1 \\
\end{array}$ & $\begin{array}{r}83.5 \sim \\
95.7\end{array}$ & $\begin{array}{r}105.3 \sim \\
121.1\end{array}$ & $\begin{array}{r}4.78 \sim \\
6.82 \\
\end{array}$ & $\begin{array}{r}60.0 \sim \\
72.4\end{array}$ & $\begin{array}{r}3.36 \sim \\
5.24 \\
\end{array}$ & $\begin{array}{r}79.0 \sim \\
93.0\end{array}$ & $\begin{array}{r}3.39 \sim \\
4.81 \\
\end{array}$ \\
\hline 捕集効率 (\%) & \multicolumn{2}{|c|}{101.8} & \multicolumn{2}{|c|}{5.1} & \multicolumn{2}{|c|}{6.5} & \multicolumn{2}{|c|}{4.8} \\
\hline
\end{tabular}

* 定置型測定器ピンホールサンプラー 
表7 新開発および市販の携帯型空中浮遊菌測定器のルテウス球菌捕集性能

\begin{tabular}{|c|c|c|c|c|c|c|c|c|}
\hline \multirow{3}{*}{$\begin{array}{c}\text { ルテゥス球菌 } \\
\text { 菌液濃度 } \\
\left(4.5 \times 10^{6} \mathrm{CFU} / \mathrm{mL}\right)\end{array}$} & \multirow{2}{*}{\multicolumn{2}{|c|}{$\begin{array}{c}\text { 新開発測定器 } \\
\text { 測定器A }\end{array}$}} & \multicolumn{6}{|c|}{ 市販測定器 } \\
\hline & & & \multicolumn{2}{|c|}{ 測定器B } & \multicolumn{2}{|c|}{ 測定器C } & \multicolumn{2}{|c|}{ 測定器D } \\
\hline & 基準器* & $A$ & 基準器* & B & 基準器* & C & 基準器* & D \\
\hline $\begin{array}{c}\text { 平均コロニー数 } \\
(\mathrm{CFU} / 28.3 \mathrm{~L})\end{array}$ & 50 & 49.8 & 45.9 & 13.5 & 45.8 & 1.9 & 42 & 1.4 \\
\hline 95\%信頼区間 & $\begin{array}{r}44.7 \sim \\
55.3\end{array}$ & $\begin{array}{r}45.3 \sim \\
54.3\end{array}$ & $\begin{array}{r}40.5 \sim \\
51.3\end{array}$ & $\begin{array}{r}11.8 \sim \\
15.1\end{array}$ & $\begin{array}{r}40.7 \sim \\
50.8\end{array}$ & $\begin{array}{r}1.28 \sim \\
2.52\end{array}$ & $\begin{array}{r}37.2 \sim \\
46.9\end{array}$ & $\begin{array}{r}0.61 \sim \\
2.19\end{array}$ \\
\hline 捕集効率 (\%) & \multicolumn{2}{|c|}{99.6} & \multicolumn{2}{|c|}{29.4} & \multicolumn{2}{|c|}{4.1} & \multicolumn{2}{|c|}{3.3} \\
\hline
\end{tabular}

*定置型測定器ピンホールサンプラー

\section{引用文献}

1）山嵪省二：環境微生物の測定と評価, オーム社, p5-6 (2001)

2) Wolf H.W.:Sampling microbiological aerosols. Public Health Monograph No.60 Public Health Service Publication No.686. U.S. Dept. of Health, Education and Welfare, Washington, D.C. (1959)

3) Brachman P.S.:Standard sampler for assay of airborne microorganisms. Science, 144, 1295 (1964)

4) NASA:Standard procedures for the microbiological examination of Space Hardware. NHB, August, 5340-1(1967)

5) NASA:Standards for clean room and work stations for the microbially controlled environment. NHB, August, 5340-2 (1967)

6) Gregory P.H. and Monteith J.L. :Airborne microbes. Cambridge University Press. (1967)

7) Dimmick R. L. and Akers A.B.:An introduction to experimental aerobiology. Wiley-Interscience. (1969)

8）山㟝省二：空気細菌測定法. 空気清浄 17(7), 26-33 (1980)

9）バイオインダストリー協会：平成2年度工業技 術院委託調査研究「バイオプロセスの標準化に 関する調查研究」成果報告書，7-74(1991)

10）山㠃省二, 杉田直記, 国安修, 上村裕, 木村正 伸, 森地敏樹: 空中細菌測定器の捕集性能試験 方法に関する研究. 第12回空気清浄とコンタミ ネーションコントロール研究大会予稿集, 207210(1993)

11）JIS K3836：空中浮遊菌测定器の捕集性能試験 方法 (1995)

12）仲田幸博, 杉田直記, 三上壮介, 尾之上さくら, 山㟝省二：携帯型空中浮遊細菌サンプラーの開 発. 第17回空気清浄とコンタミネーション研究 大会予稿集，113-116(1999） 